\title{
The Blackness in The Bluest Eye
}

Roy Xavier T.

Research Scholar, Ph.D. (English)

Bharathiar University

Coimbatore, Tamil Nadu, India

roytxavier@gmail.com

Dr. A. J. Manju

M.A., M.Phil., B.Ed., Ph.D.

Associate Professor

Department of English

Sree Narayana Guru College

Coimbatore, Tamil Nadu, India

\section{Abstract}

Novels, of any time, carry certain stories related to reality. The earlier forms of the Novel, Allegory and Romance, contained religious, philosophical facts. These literary genres took the shape of Novels, which continue to carry moral, philosophical and historical truths.

George Meredith, a Victorian novelist, defined Novel as the 'summary of actual life'. According to William Henry Hudson, an English writer, Novel is an effective medium of the portrayal of human thoughts and actions.

The English word, Novel derived from the Italian term, Novelle, which means 'a fresh story'. It was in 1350 that the Italian writer, Giovanny Boccassio, wrote his world famous collection of love stories in prose, named Decameron. Such stories in prose were called 
'novelle' and a story in verse was known as 'romance'. It meant a story of the legendary past. Malory's Morte d'Arthur is an example. Some experts gave various definitions for a 'Novel'. According to an American novelist, F. Marion Crawford, a Novel is a pocket theatre; a novel contained all accessories of a drama without requiring to be staged before an audience.

George Meredith, an English novelist, called it a 'summary of actual life' including both 'the within and the without'. According to W.H Hudson, Novel is an effective medium of the portrayal of human thought and action, 'combining in itself the creations of poetry, the details of history and generalised experience of philosophy'.

Toni Morrison's 'The Bluest Eye' (1970) is an example of a Novel, which gives a 'summary of actual life' of the Black people who had been suffering the racial discrimination in the United States of America. And 'The Bluest Eye' exists to be an 'effective medium of the portrayal of human thoughts and action', giving the details from history. The people were discriminated as the colour of their skin in America. The novel digs out the history of slavery or human trade in America which continued for some 300 years. Trade in human beings or slavery dates from prehistoric times. The Africans had been the prey to every people who traded slaves. They were transported to Egypt, Middle East, Portugal and America. For about three centuries, European nations ran the trade of supplying slaves to the Spanish and Portuguese colonies in South America and North America following the growth of plantations. The Portuguese, the Dutch, the French, the British and the Swedish joined in the human trade.

The slavery continued in America even after the attainment of its independence in 1776. The enslavement of African-American to the present United States began during the 1630's and 1640's. The slaves served their masters for life. Slavery in the U S ended in the 1860's. It was in January 1863, that Abraham Lincoln's Emancipation Proclamation came. Lincoln was assassinated by John Wilkes Booth who hated abolitionism and the President, 
Lincoln. It was a setback to the US people and the Blacks in particular. And in 1964, The Civil Rights Act was enacted. This Act outlawed discrimination based on race, colour, religion, sex or nation of origin. It was much important as far as the Blacks were concerned. The Legislation was first proposed by President John F. Kennedy in June 1963. But Kennedy was assassinated on November 22, 1963. President Johnson pushed and got it passed on July 22, 1964. The act could control the discrimination against the Blacks, to a certain extent. Martin Luther King Jr. was himself a Black who fought for the rights of the Black people in America. He had been a spokesperson and a leader in the Civil Rights Movement from 1955 until his assassination in 1968.

Toni Morrison was born as Chloe Anthony Wofford on February 18, 1931, in the small town of Lorain, Ohio. Her parents were George and Ramah Willis Wofford. Morrison was the second of the four children. She grew up in the hard times of the Great Depression of the 1930's. Though most of the people in Lorain were poor, there was not much racial segregation. As a child, Morrison experienced enough poverty, hatred and racism which left deep influence to last her a lifetime. She was much concerned about the struggling masses due to racism, poverty etc. Morrison's grandmother acquainted her with the black lore which influenced her very much in writing about the bad times of the Negroes. Her grandfather Solomon, influenced her to become a writer. He was a carpenter and also a violinist. African- American folklore is the basis of the different forms of writing which came later. Teaching of slaves were not permitted in those times. So, it was through folklores that the values were carried to the new generations. The quest for freedom, the nature of civil and the impressive poems of the helpless became the themes of African- American literature. The folklores contained the feelings, problems and dreams of the black people in the United States of America. As a Black woman, Toni Morrison was fully aware of the wrongs the Blacks suffered. There were rules prohibiting the teaching of slaves in 1830's. It was 
necessary for the oral tradition to carry the values which the Blacks considered important. Toni Morrison was much influenced by folklores which held morals for the improvement of the Blacks.

Toni Morrison used her novels, especially The Bluest Eye, as medium of exploring the meaning of blackness. She considered her writing as 'archaeological explorations' to see what it means to be a Black in White America, and to be a Black woman in a White patriarchal society. Eleven-year -old Pecola is a poor, ugly, black girl who longs to have blue eyes and she hopes this will bring her the love she longs for and can bring peace in her home. The title 'The Bluest Eye', indicates the main protagonist, Pecola's longing for blue eyes. Blue eye is the identification mark of the whites. Moreover, the title reveals the significance of the blues; the traditional art form of the blacks' story telling. The 'Eye' refers not only to Pecola's longing for blue eyes but also to the 'eye' that takes Pecola as its subject and to the 'I' who narrates her story. In other words, 'The Bluest eye' is Claudia's 'BLUES' for Pecola and her community. In the novel, Pecola's desire for blue eyes effects a community absorbed by 'White' ideas of what is beautiful. Morrison began to write the novel in 1967. She wanted to write a story for the Black people and of the Black people, unlike many Black writers whose stories she had read. Those writers, Richard Wright, Ralph Ellison and James Baldwin et al., seemed as if they were always writing to a White audience. It was in the winter of 1967, Martin Luther King Jr., and his co-workers were marching for the rights of the Blacks raising the slogan, 'Black is beautiful'. Morrison took inspiration from the slogan, Black is Beautiful.

A young Black girl, Pecola wants blue eyes, is raped by her father, goes mad and dies. Claudia Mac Teer narrates the story of Pecola who is growing up with them in the steel making Cleveland, suburb of Lorain in 1941. Pecola feels that blue eyes are the symbol of whiteness, of pride and security. She approaches a spoiled priest Soaphead Church and 
ultimately through madness, she believes blue eyes have been granted to her. There are vivid scenes that of her crippled mother and her drunken father, pregnant by her father, she goes to Soaphead Church, a man who believes himself possessed of holy powers and the young Cholly Breedlove (later to be Pecola's father)caught during the sex act by white men and being forced to continue for their amusement. The Bluest Eye can be taken as story of three Black school girls growing up in 1940's, Ohio, the sisters Claudia and Frieda Mac Teer and their friend Pecola Breedlove. Claudia and Frieda's parents are strict, protective and loving. Pecola is ignored by her mother and abused by her father. Claudia is strong-willed and hesitant to accept white dolls as symbol of beauty; whereas Pecola is crazy of becoming like White girl having blue eyes. She loves drinking milk out of Claudia's Shirley Temple cup and loves eating Mary Jane candies. Claudia has self-esteem but Pecola is lonely and sad.

Toni Morrison desires to show the pathetic condition of Black children, particularly of Black girls, through the character of Pecola Breedlove. Morrison uses blues, the traditional art form of the Blacks for this purpose. Blues, which originated in the Deep South of the US, has a deep root in American history, especially in African-American history. The slaves and ex slaves were the inventors of this musical art. Blues, generally, exhibits a lyrical progression from an initial statement of loss to a concluding statement of resolve to move on, literally and figuratively. The novel brings out the problems faced by Pecola and the ways through which she gets resolutions like a blues does. The resolution is that Pecola goes mad! A blues is sung by a person himself who faces troubles, but, The Bluest Eye is a blues sung by Claudia on behalf of Pecola, a black girl. In a way, the Novel itself is a blues- of the blacks, for the blacks and by a black-Toni Morrison! 


\section{References}

Toni Morrison, The Bluest Eye, Vintage Books, London,1999.

Shakti Batra, The Bluest Eye (A critical Study) Rama Brothers India Pvt.Ltd,2013

B. Prasad, A Background to the study of English literature, 2008.

T.K Gangadharan, History of United States of America.

C.P Hil, Amercan Aikyanadinte Charithram (Malayalam). 